\title{
Effects of Freezing Milk Samples on the Recovery of Alimentary Pathogens and Indicator Microorganisms
}

\author{
M. HUBÁČKOVÁ, D. RYŠÁNEK \\ Veterinary Research Institute, Brno, Czech Republic \\ Received November 1, 2006 \\ Accepted March 13, 2007
}

\begin{abstract}
Hubáčková M., D. Ryšánek: Effects of Freezing Milk Samples on the Recovery of Alimentary Pathogens and Indicator Microorganisms. Acta Vet. Brno 2007, 76: 301-307.

The objective of the present study was to determine the effects of freezing and subsequent storage on quantitative results of bacteriologic culturing of selected alimentary pathogens and indicator microorganisms in milk. Two model experiments were carried out. In the first experiment, raw milk samples were frozen and stored at $-20^{\circ} \mathrm{C}$ for 72 hours, 7 days or 21 days. After thawing, the following counts of indicator microorganisms were assessed: total bacteria count and counts of coliform and psychrotrophic microorganisms. The counts of these microorganisms determined before freezing served as control. In the second experiment, milk samples were inoculated with strains of shigatoxigenic Escherichia coli, enterotoxigenic Staphylococcus aureus and bacteria Listeria monocytogenes and frozen. After storage for the above times, recovery was performed and colony-forming unit counts per millilitre were assessed. It was documented that freezing had a considerable adverse effect on the recovery of shigatoxigenic E. coli $(P \leq 0.01)$ after 7 days of storage. A decline in counts of coliform bacteria $(P \leq 0.01)$ and psychrotrophic microorganisms $(P \leq 0.01)$ was detected as soon as after 72 hours storage. The decline in counts of $E$. coli and psychrotrophic microorganisms continued with the time of storage - 72 hours and 7 days $(P \leq 0.05)$; 72 hours and 21 days $(P \leq 0.01)$. In contrast, no effect was recorded for $L$. monocytogenes and total bacterial count. Freezing caused a slight increase $(P \leq 0.05)$ in $S$. aureus counts in milk samples after 72 hours and 7 days of storage. The results of this study indicate that the freezing of milk samples is unsuitable for sample storage before the assessment of hygienic quality because potential risk of misdiagnosis may be high.
\end{abstract}

Hygienic quality, E. coli, S. aureus, L. monocytogenes, psychrotrophic microorganisms, coliform bacteria, total bacterial count

Hygienic and health safety indicators of raw milk such as total bacterial count (RM-TBC), coliform bacteria count (CBC), psychrotrophic microorganisms count (PMC) and occurrence of pathogenic microorganisms in milk have to be assessed for objective estimation of milk quality; it is necessary to reliably detect causative agents of human alimentary diseases. Detection and identification of pathogens in raw milk is essential for monitoring the health status of mammary glands in dairy cows with respect to great economic losses in dairy herds caused by mastitis pathogens.

A number of studies have been performed to date, focusing on the ability of mastitis pathogens to survive under various conditions such as drying, freezing, heating, acidic/basic $\mathrm{pH}$ ranges, chilling and nutrient deprivation - all capable of causing cell injury. Some of them investigated the effect of freezing and storage time on the recovery of bacteria in milk, as sample freezing affects the ability of mastitis pathogens to survive. Freezing is lethal for many living systems. Some cell structures may be protected by freezing, whilst others are damaged. Accordingly, some organisms survive freezing and others do not (Biddle et al. 2004).

Most studies have shown freezing to have no effect on the recovery of $S$. aureus from milk 
samples (Luedecke et al. 1971; Pankey et al. 1987; Schukken et al. 1989; Murdough et al. 1996). In contrast, Villa nueva et al. (1991) documented that after a period of frozen storage of milk samples, the isolation percentage of $S$. aureus increased 1.5 times.

Sol et al. (2002) compared three techniques of isolation of pathogenic microorganisms: (1) a conventional culture technique (IDF 1981); (2) incubation of milk in broth, followed by a conventional culture technique; (3) freezing the whole milk sample, followed by incubation using a conventional culture technique. They found that the highest percentage of $S$. aureus was detected when the method with a freezing step was used.

Several studies have found a significant decrease in the number of $E$. coli isolates in samples after freezing (Storper et al. 1982; Pankey et al. 1987; Schukken et al. 1989). The most rapid cell death and injury occurred within the first 10 days of freezing (Restaino et al. 2001). Unlike cow milk, no marked decline in E. coli count was observed in goat milk samples after freezing at $-20^{\circ} \mathrm{C}$, and even after 730 days of storage at $-80^{\circ} \mathrm{C}$. Higher persistence of gram negative bacilli in goat milk in comparison with cow milk might be explained by the differences in milk composition as a consequence of a protective effect of milk components on bacteria during freezing (Sanchez et al. 2003).

Schukken et al. (1989) showed a decrease in the number of samples positive for E. coli and Arcanobacterium pyogenes and an increase in the number of coagulase negative staphylococci (CoNS) positive samples after freezing at $-20{ }^{\circ} \mathrm{C}$ and storage for 4,8 and 16 weeks. The CoNS increase in goat milk was documented by Sanchez et al. (2003). In contrast, some quantitative studies on freezing milk samples infected by CoNS at $-20{ }^{\circ} \mathrm{C}$ did not show any difference on the recovery of this group of microorganisms (Luedecke et al. 1971; Murdough et al. 1996).

It follows from the above studies that only very little is known about the effect of freezing on indicator bacteria: (RM- TBC, CBC and PMC) and particularly causative agents of human alimentary diseases.

Accordingly, the purpose of the present study was to investigate the effect of freezing and storage time on the counts of indicator microorganisms in raw milk samples and on the recovery of consequential causative agents of human alimentary diseases, such as shigatoxigenic strain of $E$. coli, enterotoxigenic strain of $S$. aureus, and a strain of L. monocytogenes, using model experiments. The study should contribute to the decision whether the freezing of raw milk samples is suitable or not for their storage before the assessment of their hygienic quality and health safety.

\section{Materials and Methods}

Experimental design

Indicator microorganisms

In the first experiment fresh raw milk samples were frozen and stored for different time periods. Counts (colonyforming unit per millilitre) of indicator organisms (RM-TBC, CBC and PMC) were assessed before freezing and after thawing.

\section{Pathogenic microorganisms}

In the second experiment suspensions of collection pathogenic bacteria in heat-treated milk were prepared. They were frozen and stored for different time periods. Recovery (colony- forming unit counts per millilitre) was then performed by inoculation on selective diagnostic agars.

Each of the experimental variants was tested in 8 parallel samples in duplicates.

Experimental Procedure

Indicator microorganisms

Samples

Thirty $\mathrm{ml}$ of raw milk were transferred into sterile plastic vials. The samples (except for controls) were frozen at $-18^{\circ} \mathrm{C}$ in a commercial freezer. After an appropriate storage time the samples were thawed at room temperature, diluted to $10^{-1}, 10^{-2}, 10^{-3}$ and inoculated. Each of the dilutions was tested in duplicates. 
For the determination of RM-TBC, inoculation of $1 \mathrm{ml}$ bacteria dilutions $10^{-2}$ and $10^{-3}$ by pouring of Plate count agar (MERCK, Darmstadt, Germany) was performed. After incubation for 72 hours at $30^{\circ} \mathrm{C}$, grown colonies were counted and evaluated according to the regulation CSN ISO 4833.

$\mathrm{CBC}$ was assessed by pouring the Violet red bile agar (Oxoid, Hampshire, England) on undiluted samples and $10^{-1}$ dilutions. Evaluation was performed according to the regulation CSN ISO 4832 after 24 -h incubation at $37^{\circ} \mathrm{C}$.

For the detection of PMC, dilutions $10^{-1}$ and $10^{-2}$ were used; Plate count skim milk agar (MERCK, Darmstadt, Germany) was poured on these diluted samples. After incubation for 10 days at $6.5^{\circ} \mathrm{C}$, colonies were counted again and evaluated according to the regulation CSN ISO 6730.

Pathogenic microorganisms

Samples

A bulk sample of raw cow milk with a low count of somatic cells and low total count of microorganisms was collected. Milk was heat-treated $\left(65^{\circ} \mathrm{C}, 30 \mathrm{~min}\right)$. Then sterility of milk was checked. Milk was pipetted into sterile plastic vials, $27 \mathrm{ml}$ to each. Three $\mathrm{ml}$ of bacterial suspension adjusted to $10^{3} / \mathrm{ml}$ were added to each vial. The vials containing milk samples (except for control samples) were frozen at $-18^{\circ} \mathrm{C}$ in a commercial freezer. Each experimental variant was tested in 8 parallel samples similarly as in the first experiment.

Bacterial strains

Bacterial strains from the Czech Collection of Microorganisms, Masaryk University Brno, Czech Republic (CCM) and the Collection of Animal Pathogenic Microorganisms, Veterinary Research Institute, Brno, Czech Republic (CAPM) were used in the experiments: E. coli (CCM 4724) (Strain: M. Bielaszewská. Stool; Czech Republic. Serovar O:157. Production of Vero cytotoxins VT1 and VT2, Sorbitol and $\beta$-glucuronidase negative), L. monocytogenes (CAPM 5879) (Strain: H. P. R. Seeliger, FRG, Serovar: 1/2b) and S. aureus (CCM 5756) (Strain: R.W. Bennett. Ham involved in food poisoning. Prototype strain for enterotoxin A).

\section{Recovery}

Samples of $0.1 \mathrm{ml}$ containing E. coli were inoculated by swirl plating over an entire plate surface with agar spreader on MacConkey agar (MCA) (Merck \& Co., INC., USA) in duplicates and after incubation for $24 \mathrm{~h}$ at $37^{\circ} \mathrm{C}$, colony-forming unit counts $(\mathrm{CFU} / \mathrm{ml})$ were determined. Samples of $0.1 \mathrm{ml}$ containing L. monocytogenes were inoculated by swirl with agar spreader on PALCAM agar (Oxoid, Hempshire, UK) in duplicates and cultured for $24 \mathrm{~h}$ at $35^{\circ} \mathrm{C}$. CFU/ml counts were determined. Samples of $0.1 \mathrm{ml}$ containing $S$. aureus were inoculated by swirl with agar spreader on Baird Parker agar (Merck \& Co., INC., USA) in duplicates and after incubation for $24 \mathrm{~h}$ at $37^{\circ} \mathrm{C}, \mathrm{CFU} / \mathrm{ml}$ counts were determined.

Temperature schedule was controlled by a memory thermometer Testo-H2 (Testo AG, Lenzkirch, Germany).

Statistical evaluation

To achieve the Gaussian data distribution, we carried out their simple logarithmic transformation (with logarithms base 10). CFU/ml counts were statistically evaluated after logarithmic transformation using one-level analysis of variability and by the assessment of significance of differences using the Tukey method (NIST/SEMATECH 2005). The data was processed by STAT Plus software (Matoušková et al. 1992).

\section{Results}

Freezing did not affect RM-TBC even after 21 days of storage (Table 1).

In frozen samples, a statistically significant $(P \leq 0.01)$ decline in CBC and PMC was detected as soon as after 72 hours storage; this decline further continued with the time of storage (Table 1). We noted statistically significant differences in PMC between the samples stored for 72 hours and 7 days $(P \leq 0.05)$ and also between the samples stored for 7 days and 21 days $(P \leq 0.01)$.

Freezing caused a statistically significant decrease $(P \leq 0.01)$ in CFU/ml counts of shigatoxigenic E. coli after 7 days of storage and was more profound after 21 days of frozen storage of samples. Statistically significant $(P \leq 0.05)$ differences between the samples stored for 72 hours and 7 days were detected; even greater differences $(P \leq 0.01)$ were found between the samples stored for 72 hours and 21days (Table 2).

Freezing had no effect on the recovery of L. monocytogenes (Table 2).

A slight increase $(P \leq 0.05)$ in $\mathrm{CFU} / \mathrm{ml}$ count after freezing of $S$. aureus was observed. It is noteworthy that the increase was demonstrated only after storage for 72 hours and 7 days. Afterwards, a decline in CFU/ml count was recorded; on day 21, no statistically significant differences were found in comparison with control (Table 2). 
Table 1. Effects of freezing and storage time on the count of indicator microorganisms - Tukey method for the determination of significance of differences was used

\begin{tabular}{|l|c|c|c|c|c|c|c|c|c|}
\hline \multicolumn{7}{|c|}{ INDICATOR MICROORGANISMS } \\
\hline \multirow{2}{*}{$\begin{array}{l}\text { Experimental } \\
\text { variant }\end{array}$} & \multicolumn{2}{|c|}{ Total bacterial count } & \multicolumn{3}{c|}{ Coliform bacteria } & \multicolumn{3}{c|}{ Psychrotrophic microorganisms } \\
\cline { 2 - 11 } & $\begin{array}{c}\text { Arithmetic } \\
\text { mean }\end{array}$ & Contrast & Significance & $\begin{array}{c}\text { Arithmetic } \\
\text { mean }\end{array}$ & Contrast & Significance & $\begin{array}{c}\text { Arithmetic } \\
\text { mean }\end{array}$ & Contrast & Significance \\
\hline $\mathrm{C}$ & 4.6875 & & & 1.9750 & & & 3.9000 & & \\
\hline $\mathrm{C}: \mathrm{F}_{72 \mathrm{~h}}$ & 4.6750 & & n.s. & 1.7750 & -0.2000 & $* *$ & 2.8000 & -1.1000 & $* *$ \\
\hline $\mathrm{C}: \mathrm{F}_{7 \mathrm{~d}}$ & 4.6625 & & n.s. & 1.7750 & -0.2000 & $* *$ & 2.4750 & -1.4250 & $* *$ \\
\hline $\mathrm{C}: \mathrm{F}_{21 \mathrm{~d}}$ & 4.7000 & & n.s. & 1.7375 & -0.2375 & $* *$ & 3.6625 & -0.2375 & n.s. \\
\hline $\mathrm{F}_{72 \mathrm{~h}}: \mathrm{F}_{7 \mathrm{~d}}$ & 4.6625 & & n.s. & 1.7750 & 0.0000 & n.s. & 2.4750 & -0.3250 & $*$ \\
\hline $\mathrm{F}_{72 \mathrm{~h}}: \mathrm{F}_{21 \mathrm{~d}}$ & 4.7000 & & n.s. & 1.7375 & -0.0375 & n.s. & 3.6625 & 0.8625 & $* *$ \\
\hline $\mathrm{F}_{7 \mathrm{~d}} \cdot \mathrm{F}_{21 \mathrm{~d}}$ & 4.7000 & & n.s. & 1.7375 & -0.0375 & n.s. & 3.6625 & 1.1875 & $* *$ \\
\hline
\end{tabular}

$\mathrm{C}=$ control; $\mathrm{F}_{72 \mathrm{~h}}=$ frozen and stored for 72 hours; $\mathrm{F}_{7 \mathrm{~d}}=$ frozen and stored for 7 days; $\mathrm{F}_{21 \mathrm{~d}}=$ frozen and stored for 21 days $* * P \leq 0.01 ; * P \leq 0.05 ;$ n.s. non-significant

Table 2. Effects of freezing and storage time on the count of pathogenic microorganisms - Tukey method for the determination of significance of differences was used

\begin{tabular}{|l|c|c|c|c|c|c|c|c|c|}
\hline \multicolumn{7}{|c|}{ PATHOGENIC MICROORGANISMS } \\
\hline \multirow{2}{*}{$\begin{array}{l}\text { Experimental } \\
\text { variant }\end{array}$} & \multicolumn{2}{|c|}{ Escherichia coli shigatoxigenic } & \multicolumn{2}{|c|}{ Listeria monocytogenes } & \multicolumn{3}{|c|}{ Staphylococcus aureus enterotoxigenic } \\
\cline { 2 - 11 } & $\begin{array}{c}\text { Arithmetic } \\
\text { mean }\end{array}$ & Contrast & Significance & $\begin{array}{c}\text { Arithmetic } \\
\text { mean }\end{array}$ & Contrast & Significance & \multicolumn{2}{|c|}{$\begin{array}{c}\text { Arithmetic } \\
\text { mean }\end{array}$} & \multicolumn{2}{c|}{ Contrast } & Significance \\
\hline $\mathrm{C}$ & 4.1875 & & & 3.1875 & & & 3.0300 & & \\
\hline $\mathrm{C}: \mathrm{F}_{72 \mathrm{~h}}$ & 4.1125 & -0.0750 & n.s. & 3.3500 & & n.s. & 3.1362 & 0.1063 & $*$ \\
\hline $\mathrm{C}: \mathrm{F}_{7 \mathrm{~d}}$ & 4.0125 & -0.1750 & $* *$ & 3.1750 & & n.s. & 3.1475 & 0.1175 & $*$ \\
\hline $\mathrm{C}: \mathrm{F}_{21 \mathrm{~d}}$ & 3.9875 & -0.2000 & $* *$ & 3.1875 & & n.s. & 3.0450 & 0.0150 & n.s. \\
\hline $\mathrm{F}_{72 \mathrm{~h}}: \mathrm{F}_{7 \mathrm{~d}}$ & 4.0125 & -0.1000 & $*$ & 3.1750 & & n.s. & 3.1475 & 0.0112 & n.s. \\
\hline $\mathrm{F}_{72 \mathrm{~h}}: \mathrm{F}_{21 \mathrm{~d}}$ & 3.9875 & -0.1250 & $* *$ & 3.1875 & & n.s. & 3.0450 & -0.0912 & n.s. \\
\hline $\mathrm{F}_{7 \mathrm{~d}} \cdot \mathrm{F}_{21 \mathrm{~d}}$ & 3.9875 & -0.0250 & n.s. & 3.1875 & & n.s. & 3.0450 & -0.1025 & n.s. \\
\hline
\end{tabular}

$\mathrm{C}=$ control; $\mathrm{F}_{72 \mathrm{~h}}=$ frozen and stored for 72 hours; $\mathrm{F}_{7 \mathrm{~d}}=$ frozen and stored for 7 days; $\mathrm{F}_{21 \mathrm{~d}}=$ frozen and stored for 21 days

$* * P \leq 0.01 ; * P \leq 0.05 ;$ n.s. non-significant

\section{Discussion}

One of the available methods of mastitis control, hygienic inspection and monitoring health safety of milk is the identification of microorganisms present in milk by culture examination methods. The ability to freeze and store milk samples without the loss of the microorganisms is essential so that misdiagnosis can be prevented. A number of studies focused on the effect of freezing on detectability of microorganisms, particularly mastitis causing pathogens. To our knowledge, none of them investigated the effect of freezing and storage of milk samples on indicator microorganisms and human alimentary pathogens.

In this study, freezing had a significant adverse effect on the recovery of shigatoxigenic E. coli strain, and caused depression in the $\mathrm{CBC}$ and PMC. The decrease further continued with the time of storage. In contrast, no effect was found for L. monocytogenes strain and RM-TBC. Freezing caused a slight increase in counts in samples containing S. aureus.

Previous studies reported adverse effects of freezing on E. coli survival (Storper et al. 1982; Pankey et al. 1987; S chukken et al. 1989). Similar effects on shigatoxigenic strain $E$. coli were observed in our study. Hence, shigatoxigenic strains do not seem to be more 
resistant to freezing than non-toxigenic strains. It follows that frozen samples are not suitable for microbiological analysis of foodstuffs that probably caused alimentary intoxication.

Freezing caused a slight, but significant increase in counts in samples containing enterotoxigenic S. aureus. Similar effect was observed by Villanueva et al. (1991) with non-toxigenic strains of S. aureus. Hence, non-toxigenic and toxigenic strains of S. aureus can survive freezing well, and even increase in counts. The increase was probably caused by the fact that the freezing process may cause rupture of milk macrophages and neutrophils, releasing phagocytised bacteria. Freezing may also disrupt bacterial cell aggregates (Villanueva et al. 1991; Godden et al. 2002).

L. monocytogenes can survive freezing very well; freezing does not cause damage to their cells and the duration of frozen storage does not affect their culture rate. These results are supported by the fact that frozen milk products (ice-cream, frozen creams) have caused outbreaks of listeriosis (Baek et al. 2000; Windrantz and Arias 2000; Cordano and Rocourt 2001).

We did not observe any effect of freezing on RM-TBC. However, RM-TBC can occur from a variety of microorganisms and from a variety of sources. While microbial contamination from within the udder of healthy animals is not considered to contribute significantly to the total numbers of microorganism in the bulk milk, cows with mastitis have the potential to shed large numbers of microorganisms into the milk supply (Murphy and B oor 2000). Mastitis organisms found to most often influence the total bulk milk count are bacteria of Streptococcus spp. S. aureus is not thought to be a frequent contributor to total bulk milk counts. Of more importance is the contribution of microorganisms from teats soiled with manure, mud, feeds or bedding (Holm et al. 2004). These organisms include streptococci, staphylococci, spore-formers, coliform and other gram-negative bacteria. Less efficient cleaning, using lower temperatures and/or the absence of sanitizers tends to select for the faster growing, less resistant organisms, principally gram-negative rods (coliforms and pseudomonads). In general, gram-negative bacteria are more susceptible to freezing than gram-positives (Archer 2004). Consequently, it could be presumed that when gram-negative bacteria are predominant in RM-TBC, their count may be significantly changed by freezing.

Refrigeration of raw milk creates selective conditions for the growth of psychrotrophic bacteria, particularly Pseudomonas spp. Many pseudomonads have the genetic competence to elaborate heat-stable proteinases and lipases which attack the protein and lipid components of milk (Rowe et al. 2001). Accordingly, their count is very important for milk quality assessment. Psychrotrophic bacteria were adversely affected by freezing in the present experiment. Their count decreased significantly after frozen storage for $72 \mathrm{~h}$. It follows that frozen samples are not suitable for the determination of their count.

A considerable decline in $\mathrm{CBC}$ after frozen storage of samples for $72 \mathrm{~h}$ confirmed an increased susceptibility of gram-negative bacteria to freezing, as was also found for $E$. coli and psychrotrophic microorganisms.

It follows from the present study that frozen samples are not suitable for the determination of hygienic quality of milk because $\mathrm{CBC}$ and PMC significantly decrease due to freezing. The freezing of milk samples is likewise unsuitable for the detection of causative agents of human alimentary diseases because the freezing and thawing of milk samples brings about a decline in shigatoxigenic E. coli counts. Accordingly, the risk of potential misdiagnosis may be high.

\section{Vliv zmražení vzorků mléka na recovery alimentárních patogenů a indikátorových mikroorganismů}

Předmětem této studie je zhodnocení vlivu zmražení a následného uchovávání vzorku mléka na kvantitativní výsledky bakteriologické kultivace vybraných alimentárních patogenů a indikátorových mikroorganismů. Byly provedeny dva experimenty. V prvním experimen- 
tu byly vzorky syrového mléka zamraženy a uchovávány při teplotě $-20^{\circ} \mathrm{C}$ po dobu 72 hodin, 7 dní a 21 dní. Po rozmražení vzorkủ byl stanoven počet těchto indikátorových mikroorganismů: celkový počet mikroorganismů, počet koliformních bakterií a počet psychrotrofních mikroorganismů. Počet těchto mikroorganismů před zamražením sloužil jako kontrola. V druhém experimentu byly vzorky mléka naočkovány kmeny shigatoxigenní E. coli, enterotoxigenní S. aureus a bakterií Listeria monocytogenes a zamraženy. Vzorky byly uchovávány po dobu 72 hodin, 7 dní a 21 dní ve zmraženém stavu a po rozmražení bylo provedeno zpětné stanovení bakterií a byly stanoveny počty kolonie-tvořících jednotek na mililitr. Bylo prokázáno, že zmražení má výrazně nepř́íznivý vliv na zpětné stanovení shigatoxinogenních $E$. coli $(P \leq 0.01)$ po 7 dnech uchovávání. Byl zaznamenán úbytek počtu koliformních bakterií $(P \leq 0.01)$ a psychrotrofních mikroorganismů $(P \leq 0.01)$ již po 72 hodinách. Pokles počtu $E$. coli a psychrotrofních mikroorganismů se prohluboval s délkou úchovy v zamraženém stavu po 72 hodin a 7 dní $(P \leq 0.05)$; 72 hodin a 21 dní $(P \leq 0.01)$. Naopak nebyl zaznamenán vliv zmražení na $L$. monocytogenes a na celkový počet mikroorganismů. Zmražení způsobilo mírný nárůst počtu $S$. aureus $(P \leq 0.05)$ ve vzorcích mléka po 72 hodinách a 7 dnech skladování. Výsledky této studie ukazují, že vzorky určené $\mathrm{k}$ hodnocení hygienické kvality mléka nelze uchovávat $\mathrm{v}$ zamraženém stavu, protože výsledky mohou být zmražením výrazně ovlivněny.

\section{Acknowledgement}

This study was supported by the Ministry of Agriculture of the Czech Republic (MZE 0002716201).

\section{References}

ARCHER DL 2004: Freezing: an underutilized food safety technology? Int J Food Microbiol 90: 127-138

BAEK SY, LIM SY, LEE DH, MIN KH, KIM CM 2000: Incidence and characterization of Listeria monocytogenes from domestic and imported foods in Korea. J Food Protect 63: 186-189

BIDDLE MK, FOX L, HANCOCK DD, GASKINS CT, EVANS MA 2004: Effects of storage time and thawing methods on the recovery of Mycoplasma species in milk samples from cows with intramammary infections. J Dairy Sci 87: 933-936

CORDANO AM, ROCOURT J 2001: Occurrence of Listeria monocytogenes in food in Chile. Int J Food Microbiol 70: $175-178$

GODDEN SM, JANSEN JT, LESLIE KE, SMART NL, KELTON DF 2002: The effect of sampling time and sample handling on the detection of Staphylococcus aureus in milk from quarters with subclinical mastitis. Can Vet J 43: 38-42

HOLM C, JEPSEN L, LARSEN M, JESPERSEN L 2004: Predominant microflora of downgraded Danish bulk tank milk. J Dairy Sci 87: 1151-1157

IDF 1981: International Dairy Federation Bull. 132. Bovine mastitis. Definitions and guidelines for diagnosis. Chapter 2: Isolation and Identification of mastitis bacteria. Brussels 1981, pp. 17-27

LUEDECKE LO, FORSTER TL, WILLIAMS K, HILLERS JK 1971: Effect of freezing and storage at $-20^{\circ} \mathrm{C}$ on survival of mastitis pathogens. J Dairy Sci 55: 417-418

MATOUŠKOVÁ O, CHALUPA J, CÍGLER M, HRUŠKA K 1992: STAT Plus, software manual 1.01. Veterinary Research Institute, Brno, 168 p.

MURPHY SC, BOOR KJ 2000: Trouble-shooting sources and causes of high bacteria counts in raw milk. Dairy Food Environ Sanit 20: 606-611

MURDOUGH PA, DEITZ KE, PANKEY JW 1996: Effects of freezing on the viability of nine pathogens from quarters with subclinical mastitis. J Dairy Sci 79: 334-336

NIST/SEMATECH e-Handbook of Statistical Methods, has been published on CD as NIST Handbook 151, 2005. Available at http://www.itl.nist.gov/div898/handbook

PANKEY JW, WADSWORTH JK, METHA KH, MURDOUGH PA 1987: Effects of storage on viability of mastitis pathogens. J Dairy Sci 70 (Suppl. 1): 132

RESTAINO L, FRAMPTON EW, SPITZ H 2001: Repair and growth of heat- and freeze-injured Escherichia coli O157:H7 in selective enrichment broths. Food Microbiol 18: 617-629

ROWE MT, DUNSTALL G, KILPATRICK D, WISDOM GB 2001: A study of changes in the psychrotrophic microflora of raw milk during refrigerated storage. Milchwissenschaft 56: 247-250

SANCHEZ A, CONTRERAS A, JIMENEZ J, LUENGO C, CORRALESM JC, FERNANDEZ C 2003: Effect of freezing goat milk samples on recovery of intramammary bacterial pathogens. Vet Microbiol 94: 71-77

SCHUKKEN YH, SMIT JAH, GROMMERS FJ, VANDEGEER D, BRAND A 1989: Effect of freezing on bacteriologic culturing on mastitis milk samples. J Dairy Sci 72: 1900-1906 
SOL J, SAMPIMON OC, HARTMANE E, BARKEMA HW 2002: Effect of preculture freezing and incubation on bacteriological isolation from subclinical mastitis samples. Vet Microbiol 85: 241-249

STORPER M, ZIV G, SARAN A 1982: Effect of storing milk samples at $-18^{\circ} \mathrm{C}$ on the viability of certain udder pathogens. Refuah Vet 39: 1-2

VILLANUEVA MR, TYLER JW, THURMOND MC 1991: Recovery of Streptococcus agalactiae and Staphylococcus aureus from fresh and frozen bovine milk. J Am Vet Med Assoc 198: 1398-1400

WINDRANTZ P, ARIAS ML 2000: Evaluation of the bacteriological quality of ice cream sold at San Jose, Costa Rica. Arch Latinoam Nutr 50: 301-3 